\title{
PENINGKATAN KADAR LEPTIN DENGAN PUFA (Polyunsaturated Fatty Acid) MELALUI AKTIVASI PEROXISOME PROLIFERATOR-ACTIVATED RECEPTOR gamma (PPARY) PADA KULTUR PREADIPOSIT KELINCI
}

\section{INCREASING LEPTIN LEVELS WITH PUFA (Polyunsaturated Fatty Acid) BY PEROXISOME PROLIFERATOR-ACTIVATED RECEPTOR gamma (PPAR $\gamma$ ) ACTIVATION ON RABBIT PREADIPOCYTE CULTURE}

\author{
Muhammad Rasjad Indra \\ Laboratorium IImu Faal Fakultas Kedokteran Unibraw Malang
}

\begin{abstract}
For the past three decades, PUFA has been recognized as importnant energy sources and cell membrane component. PUFA also plays key roles in many cellular events such as gene regulation and leptin activation. The role of this fatty acid is still unknown especially in vitro. The purpose of this research was to examine the effect of PUFA of the corn oil in increasing leptin concentration by PPAR ractivation. Preadipocyte culture from rabbit was incubated by PUFA of corn oil. PUFA have been given on doses 0, 4, 8 and $16 \mu \mathrm{M}$. PPAR $\gamma$ protein and leptin levels were analyzed by ELISA. PPAR $\gamma$ expression was analyzed by immunocytochemistry. The research result showed that every treatment has increased PPARY levels inconsistently. PPARY concentration increased significantly on $4 \mu M$ PUFA treatment compared to control, 8 and $16 \mu M$ PUFA of corn oil. But there were no significant difference between control and $8 \mu M$ PUFA treatments. Leptin levels increased significantly between administration on $4 \mu M$ PUFA and $16 \mu M$ PUFA of corn oil administration. Leptin levels was not significantly different between control and $8 \mu M$ PUFA. There was also strong correlation between PPARy expression and leptin levels. PUFA of corn oil increases leptin levels through PPARY activation.
\end{abstract}

Key words: PUFA, preadipocyte, leptin, PPARY

\section{PENDAHULUAN}

Polyunsaturated fatty acid (PUFA) $\omega-3$ dan $\omega-6$ (linoleat dan linolenat) merupakan asam lemak esensial yang tidak dapat disintesis oleh mamalia dan senyawa ini diperoleh melalui sumber makanan. Salah satu sumber PUFA adalah minyak jagung. Diet PUFA dapat mengurangi akumulasi trigliserid di jaringan, sedangkan rendahnya lipid dalam jaringan berhubungan dengan penurunan risiko sindroma metabolik (1). PUFA berperan dalam pembentukan struktur membran sel, metabolisme sel sel, dan merupakan ligan natural Peroxisome Proliferator-Activated Receptor (PPAR) tetapi peranan asam lemak ini masih belum banyak diketahui terutama secara in vitro (2). Oleh karena itu perlu dilakukan penelitian agar pemahaman tentang mekanisme PUFA dalam sinyal transduksi lebih jelas.

PPAR (Peroxisome Proliferator-Activated receptors) merupakan reseptor inti yang diaktifkan oleh ligand natural, antara lain asam lemak dan eicosanoid (lekotrien, prostaglandin) dan beberapa agonist farmakologis seperti pioglitazone. Setelah berikatan dengan peroxisome prolife-

Jurnal Kedokteran Brawijaya, Vol. XXI, No.2, Agustus 2005

Korespondensi: M. Rasjad Indra; Lab. IImu Faal FK Unibraw Malang; Telp. (0341) 580993 ext 115

Email: rasjad@fk.unibraw.ac.id rator response elements (PPRE), PPAR yang teraktifasi selanjutnya akan meregulasi transkripsi beberapa gen yang antara lain mengkontrol metabolisme sel lipid bahkan juga glukosa serta siklus sel dan respon imun. Beberapa penelitian menyimpulkan bahwa PPARy meningkatkan ekspresi leptin di adiposit.

Leptin adalah hormon yang disintesis terutama oleh adiposit dan memiliki peran penting pada homeostasis energi. Mekanisme dasar pengendalian ekspresi gen leptin di jaringan lemak putih maupun lemak coklat masih belum diketahui secara jelas.

Umpan balik ekspresi gen leptin di jaringan lemak coklat terutama melalui mediasi efek leptin pada sistem saraf simpatis oleh sistem saraf pusat, sedangkan pengendalian ekspresi leptin pada jaringan lemak putih nampaknya melalui mekanisme yang tidak tergantung pada aktifitas sistem saraf simpatis.

Pengendalian kadar leptin oleh diet sudah dibuktikan oleh beberapa peneliti. Restriksi maupun pengembalian diet dapat mempengaruhi kadar leptin plasma dan ekspresi gen ob pada rodensia maupun manusia $(3,4)$. Dalam hal ini, restriksi menurunkan sedangkan refeeding meningkatkan kadar leptin kembali $(5,6)$. Sinyal metabolik yang mengubah fungsi adiposit termasuk sintesis leptin dan reseptornya masih belum banyak diketahui. Sementara Peroxisome Proliferators Activated Receptor-y (PPARy) yang salah satu 
ligand alaminya adalah PUFA diketahui merupakan regulator utama dalam diferensiasi dan fungsi adiposit. Dengan demikian perlu diteliti seberapa jauh kandungan PUFA dalam minyak jagung dapat meningkatkan sintesis leptin adiposit secara in vitro untuk mendasari penatalaksanaan obesitas dan sindroma metabolik melalui diet.

\section{METODE}

\section{Isolasi Preadiposit dan Kultur Adiposit}

Setelah dipelihara 2 minggu, kelinci dibunuh dan diambil jaringan lemak omentum untuk dilakukan kultur sel adiposit. Jaringan lemak dicuci dengan PBS free Ca sebanyak 3 kali. Jaringan dicacah sampai $1 \mathrm{~mm}^{2}$ dalam media serum free. Sel diisolasi dengan $0,02 \mathrm{~g} / \mathrm{mL}$ Collagenase type I (Gibco BRL) dalam media serum free. Suspensi sel diinkubasi $37^{\circ} \mathrm{C}$ selama 3 jam. Suspensi sel disaring dengan filter nilon $250 \mu \mathrm{m}$. Filtrat diputar $2000 \mathrm{rpm}$ selama 7 menit. Pelet yang mengandung stromal vascular cell diresuspensi dengan media serum free. Sel diputar 2000 rpm selama 5 menit. Pelet diresuspensi dalam media kultur (DMEM/F12 Ham (1:1), 2 mM L-Glutamin, 25 mM HEPES, $50 \mathrm{mg} / \mathrm{mL}$ Penstrep, $10 \mu \mathrm{M}$ Natrium Bicarbonat, $10 \%$ FBS) (7).

\section{Isolasi Protein Preadiposit Kelinci}

Isolasi protein preadiposit kelinci bertujuan untuk mendapatkan protein yang digunakan sebagai sampel dalam mengukur kadar protein PPARy. Sel kultur preadiposit kelinci dilisiskan dengan bufer lisis yang mengandung 20 $\mathrm{mM}$ Tris- $\mathrm{HCl}$ (pH 7.5), $150 \mathrm{mM} \mathrm{NaCl}, 10 \mathrm{mM}$ EDTA, $0.5 \mathrm{mM}$ (p-amidinophenyl) methanesulfonyl fluoride hydrochloride (PMSF) dan $1 \%$ Nonidet P-40. Sel diinkubasi dalam 10 menit, suhu $37^{\circ} \mathrm{C}$ selama 10 menit. Sel diputar $12000 \mathrm{rpm} 4$ ${ }^{\circ} \mathrm{C}$ selama 5 menit. Pelet dicuci dengan PBS pH 7.4 sebanyak dua kali. Pelet diresuspensi dengan PBS dan disimpan dalam freezer $-30{ }^{\circ} \mathrm{C}(2)$

\section{Pengukuran Kadar protein PPARy dan Leptin dengan ELISA (Enzyme Linked Immunosorbent Assay)}

Leptin dalam coating buffer (1:9) didapatkan dengan melarutkannya dalam TBS sampai $1 \mathrm{ml}$ hingga memiliki kadar $10 \mu \mathrm{g} / \mathrm{ml}$ dan ditambahkan coating buffer hingga 10 $\mathrm{ml}$. Antigen di-coating pada plate ELISA selama semalam pada suhu $4^{\circ} \mathrm{C}$. Dicuci dalam PBS-Tween $3 \times 3$ menit. Diblok dengan blocking buffer (BSA 1\% dalam PBS) $50 \mu \mathrm{l} /$ well. Diinkubasi selama 2 jam suhu ruang. Dicuci dalam PBSTween $3 \times 3$ menit.

Antibodi primer $(50 \mu \mathrm{l} /$ well) dimasukkan kemudian diinkubasi selama 2 jam pada suhu ruang. Dicuci dalam PBS-Tween $3 \times 3$ menit. Coating antibodi sekunder Anti Rabbit IgG AP Conjugated (1:2500) dalam TBS melalui inkubasi selama 2 jam pada suhu ruang. Dicuci dalam PBSTween $3 \times 3$ menit. Ditambahkan substrat pNPP dalam dietanolamin 10\% (50 $\mu \mathrm{l} /$ well). Diinkubasi 30 menit, suhu ruang (tidak dicuci, yang dibaca adalah pNPP yang terikat Ab sekunder). Ditambahkan $\mathrm{NaOH} 3 \mathrm{M}(50 \mu \mathrm{l} /$ well) sebagai stop reaction. Setelah 15 menit, dibaca dengan ELISA reader pada $\lambda=405 \mathrm{~nm}$.

\section{Ekspresi PPAR y dengan imunositokimia}

Untuk melihat peningkatan ekspresi protein PPAR y dan leptin digunakan metode Double Staining Immunocytochemistry (Dako - USA; Santa Cruz - USA). Setelah selesai diperlakukan, kultur adiposit dicuci dengan HEPES buffer (Sigma-USA) dan difiksasi menggunakan 4\% paraformaldehide selama 30 menit. Dibilas dengan PBS pH 7,4 dan diinkubasi menggunakan $5 \%$ blocking serum (SantaCruz) yang mengandung $0,25 \%$ triton $\mathrm{X}-100$ selama 1 jam dan dibilas dengan PBS $\mathrm{pH} 7,4$. Setelah itu diinkubasi dengan monoclonal anti PPARY (SantaCruz) selama 1 jam, dibilas dengan PBS $\mathrm{pH} 7,4$. Selanjutnya diinkubasi pada $3 \%$ $\mathrm{H}_{2} \mathrm{O}_{2}$ (Sigma-USA) selama 10 menit dan dibilas dengan PBS pH 7,4. Kemudian diinkubasi dengan link $2^{\text {nd }}$ antibody polimer labelled with SA-HRP (Dako-USA) dan dibilas dengan PBS pH 7,4, diaplikasikan DAB (SantaCruz) selama 3 menit dan dicuci dengan $\mathrm{dH}_{2} \mathrm{O}$. Diinkubasi menggunakan double staining blocking reagent (Dako-USA) selama 30 menit dan diinkubasi menggunakan monoklonal anti Leptin (SantaCruz) selama 2 jam dan dibilas dengan PBS pH 7,4. Terakhir diinkubasi pada $2^{\text {nd }}$ antibody polymer labelled with AP (Dako-USA) selama 1 jam dan dibilas dengan PBS pH 7,4 dan diaplikasikan fast red selama 10 menit. Dibilas dengan $\mathrm{dH}_{2} \mathrm{O}$ dan counterstaining menggunakan mayer hematoxillen.

\section{HASIL PENELITIAN}

Polyunsaturated Fatty acid merupakan ligan alami PPAR (peroxisome proliferator-activated receptor). Pada penelitian ini menggunakan PUFA (Polyunsaturated Fatty acid) dalam minyak jagung sebagai perlakuan kultur preadiposit kelinci untuk mengamati kadar protein PPAR $y$ dan kadar leptin. Kadar protein PPAR y dan leptin ditentukan dengan ELISA dan pengamatan keberadaan leptin dengan Imunositokimia. Kadar PUFA yang digunakan adalah 0

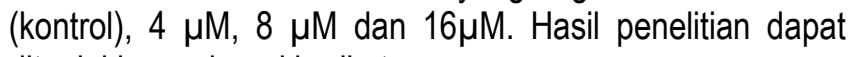
ditunjukkan sebagai berikut :

\section{Pengaruh PUFA dalam Minyak Jagung terhadap Kadar protein PPARy}

Kadar protein PPAR y pada preadiposit kelinci setelah pemberian PUFA selama 24 jam menunjukkan peningkatan, tetapi peningkatan kadar PPARy tidak konsisten pada setiap perlakuan. Kadar protein PPAR preadiposit kelinci meningkat setelah preadiposit dipapar dengan $4 \mu \mathrm{M}$ PUFA tetapi menurun pada perlakuan $8 \mu \mathrm{M}$ dan kemudian diikuti peningkatan kadar PPARy pada perlakuan $16 \mu \mathrm{M}$ PUFA. 
Hasil analisis statistik menunjukkan bahwa kadar PPARy pada perlakuan $4 \mu \mathrm{M}$ meningkat secara nyata dibandingkan dengan kontrol, $8 \mu \mathrm{M}$ maupun $16 \mu \mathrm{M}$ PUFA, tetapi tidak didapatkan beda kadar PPARy bermakna antara kontrol dengan perlakuan $8 \mu \mathrm{M}$ PUFA seperti terlihat pada Tabel 1 ( $p \leq 0,05)$

Pada Tabel 1 dan Gambar 1 dapat disimpulkan bahwa peningkatan PUFA dapat meningkatkan kadar protein PPAR $\gamma$ preadiposit kelinci meskipun tidak konsisten.

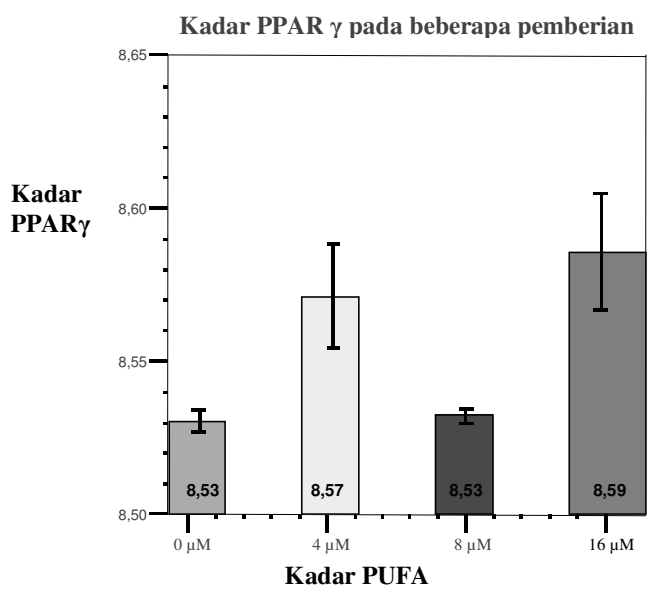

Gambar 1.Kadar PPAR $\gamma$ pada masing-masing perlakuan setelah preadiposit kelinci dipapar dengan PUFA dalam minyak jagung $(\mathrm{p} \leq 0.05)$.

Tabel 1. Rerata kadar PPAR $\gamma$ pada kultur preadiposit kelinci setelah dipapar PUFA selama 24 jam ( $p$ $\leq 0.05$ )

\begin{tabular}{llc}
\hline \multicolumn{1}{c}{ Perlakuan } & $\mathbf{N}$ & Mean $\pm \mathbf{S D}(\boldsymbol{p} \leq \mathbf{0 . 0 5})$ \\
\hline Kontrol & 24 & $8.531 \pm 0.007 \mathrm{a})$ \\
\hline $4 \mu \mathrm{M}$ PUFA & 24 & $8.571 \pm 0.034 \mathrm{~b})$ \\
\hline $8 \mu \mathrm{M}$ PUFA & 22 & $8.532 \pm 0.005 \mathrm{a})$ \\
\hline $16 \mu \mathrm{M}$ PUFA & 24 & $8.586 \pm 0.038 \mathrm{~b})$ \\
\hline
\end{tabular}

Keterangan:

Notasi yang sama menunjukkan tidak berbeda nyata sedangkan notasi yang berbeda menunjukkan berbeda signifikan.

\section{Pengaruh PUFA dalam Minyak Jagung terhadap Kadar Leptin}

Hasil pengukuran kadar leptin menunjukkan fenomena yang sama dengan kadar protein PPAR $\gamma$. Pada Gambar 2 dapat dilihat bahwa kadar leptin pada perlakuan $4 \mu \mathrm{M}$ PUFA meningkat tetapi kadar leptin menurun pada perlakuan $8 \mu \mathrm{M}$. Kadar leptin meningkat lagi setelah perlakuan dengan konsentrasi $16 \mu \mathrm{M}$ PUFA. Hasil analisis statistik menunjukkan bahwa kadar leptin pada perlakuan $4 \mu \mathrm{M}$ berbeda secara nyata dibandingkan dengan kontrol, $8 \mu \mathrm{M}$ dan $16 \mu$ M PUFA. Kadar leptin pada kontrol tidak berbeda nyata dengan perlakuan $8 \mu \mathrm{M}$ PUFA sedangkan perlakuan $4 \mu \mathrm{M}$ meningkat secara nyata dibandingkan dengan perlakuan $16 \mu \mathrm{M}$ PUFA seperti terlihat pada Tabel 2 ( $\mathrm{p}$ $\leq 0,05)$.

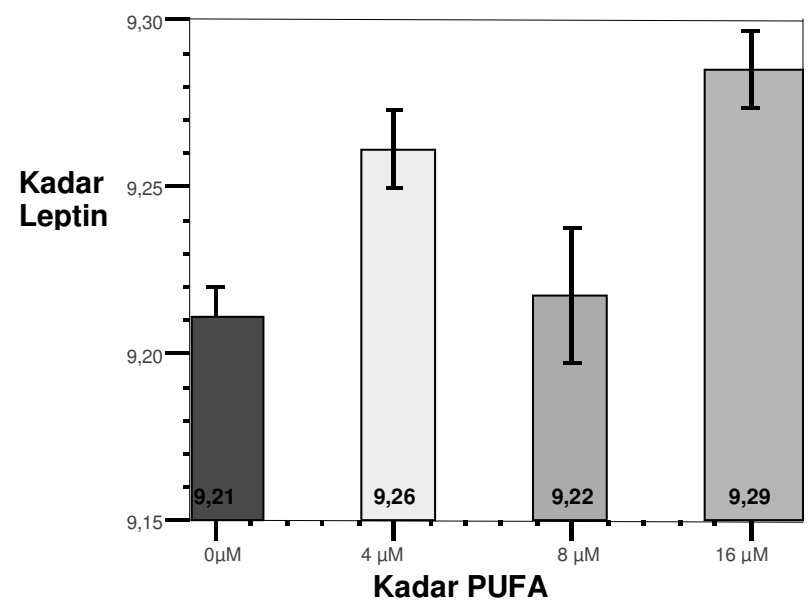

Gambar 2.Kadar Leptin pada masing-masing perlakuan setelah preadiposit kelinci diinkubasi dengan PUFA dalam minyak jagung ( $\mathrm{p} \leq 0.05)$.

Tabel 2. Rerata kadar Leptin pada kultur preadiposit kelinci setelah dipapar PUFA selama 24 jam

\begin{tabular}{llc}
\hline \multicolumn{1}{c}{ Perlakuan } & N & Mean \pm SD \\
\hline Kontrol & 24 & $9.211 \pm 0.018$ a) \\
\hline $4 \mu \mathrm{M}$ PUFA & 24 & $9.261 \pm 0.024$ b) \\
\hline $8 \mu \mathrm{M}$ PUFA & 22 & $9.209 \pm 0.010$ a) \\
\hline $16 \mu \mathrm{M}$ PUFA & 24 & $9.289 \pm 0.023$ c) \\
\hline
\end{tabular}

Keterangan.

Notasi yang sama menunjukkan tidak berbeda nyata sedangkan notasi yang berbeda menunjukkan berbeda signifikan.

Hasil pengukuran kadar leptin media sel kultur setelah dipapar PUFA menunjukkan bahwa kadar leptin berhubungan dengan peningkatan konsentrasi PUFA. Fenomena perubahan kadar leptin media sel kultur preadiposit ini berhubungan dengan perubahan kadar PPAR $\gamma$.

Interaksi antara Kadar Protein PPAR $\gamma$ dengan Kadar Leptin

Pada Gambar 3 dapat dilihat hubungan antara kadar PPAR $\gamma$ dengan leptin pada preadiposit kelinci setelah diinkubasi dengan PUFA. Persamaan regresi menunjukkan bahwa perubahan kadar PPAR $\gamma$ diikuti oleh perubahan kadar leptin dalam media sel dengan koefisien regresi dan korelasi yang cukup kuat. 


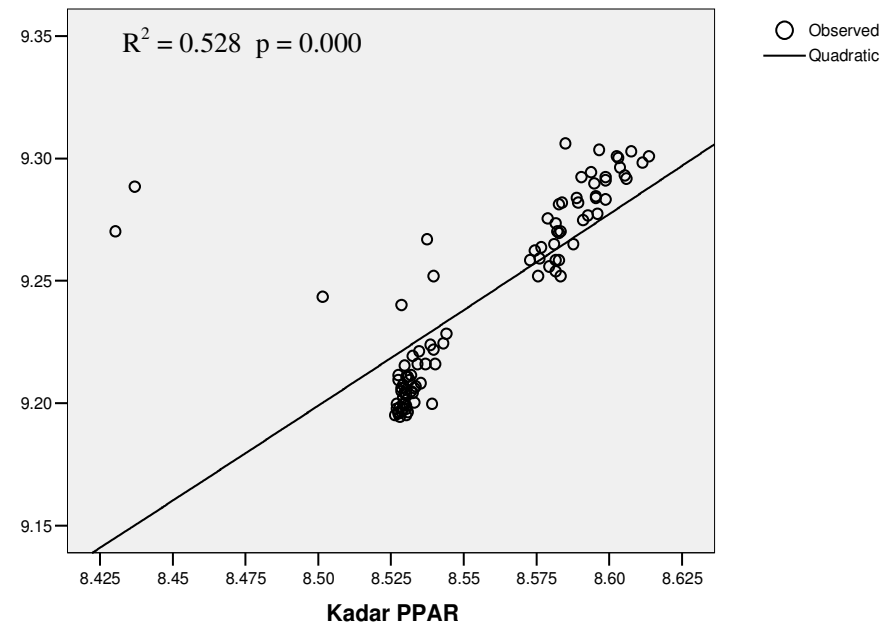

Gambar 3. Hubungan antara PPAR $y$ dan Leptin dengan persamaan kuadratik.

Keberadaan PPAR $\gamma$ pada Preadiposit Kelinci pada masing - masing perlakuan

Keberadaan PPARy pada preadiposit kelinci pada masing-masing perlakuan dianalisis dengan pengecatan imunositokimia. Hasil analisis dengan Corel Draw versi 11 menunjukkan bahwa PPARy meningkat pada perlakuan 4 $\mu$ M PUFA $(151,79 \pm 12,58)$ dibandingkan kontrol $(164,29 \pm$ $14,79)$ tetapi menurun pada perlakuan $8 \mu$ M PUFA $(161,34$ $\pm 14,03)$. Pada perlakuan $16 \mu \mathrm{M}$ PUFA $(128,27 \pm 13,47)$ meningkat secara nyata dibandingkan dengan kontrol dan perlakuan $4 \mu \mathrm{M}$ PUFA.
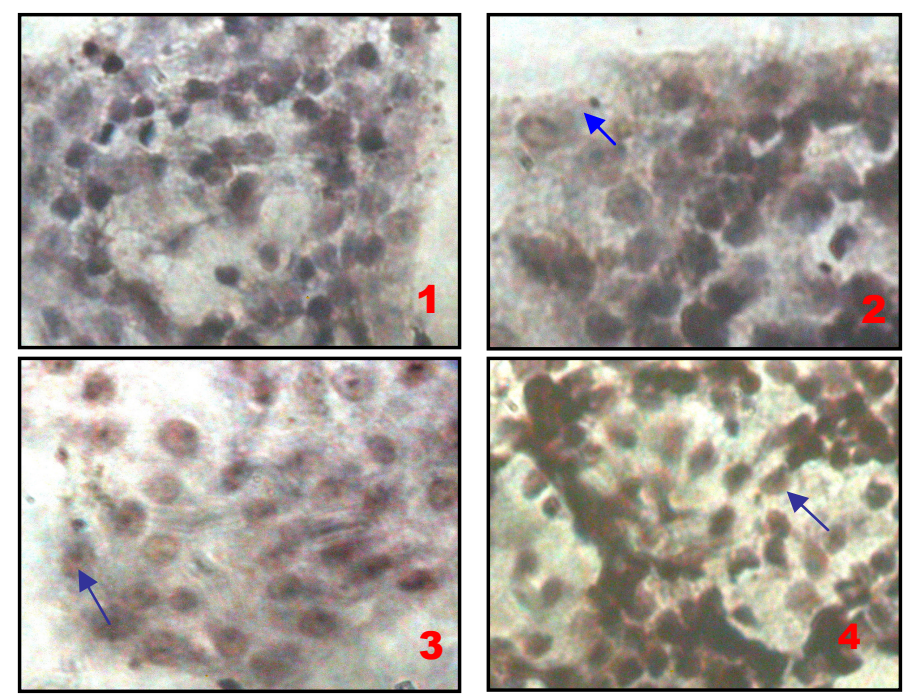

Gambar 4. Hasil identifikasi PPARy pada preadiposit kelinci setelah diinkubasi dengan PUFA dalam minyak jagung dengan Imunositokimia 1) kontrol; 2) $4 \mu \mathrm{M}$ PUFA; 3) $8 \mu \mathrm{M}$ PUFA; 4) $16 \mu \mathrm{M}$ PUFA (200 x) Tanda panah menunjukkan lokasi PPARy 


\section{DISKUSI}

Penemuan PPAR dan asam lemak sebagai ligan beberapa tahun lalu telah berhasil mengungkap mekanisme lipid sebagai modulator ekspresi gen. Temuan tersebut disusul dengan kumpulan bukti-bukti bahwa PPAR berperan dalam jaringan pengendali penegakan homeostasis energi dalam organisme. Dengan dibuktikannya bahwa mediator lipid, misalnya eikosanoid (lekotrien dan prostaglandin) adalah ligan natural PPAR, makin membuka peluang pelacakan determinan-determinan dalam novel keseimbangan energi serta fungsi PPAR dikaitkan dengan homeostasis energi, pengendalian siklus sel, inflamasi dan respons imun. Dengan demikian, PPAR merupakan target intervensi terapuetik yang menjanjikan melalui pengembangan agonis dan antagonis PPAR dalam penatalaksanaan penyakit, misalnya obesitas dan diabetes mellitus, aterosklerosis, inflamasi kronis, dan karsinogenesis (8).

Peran kunci PPARy dalam adipogenesis dan sebagai reseptor obat penambah sensitifitas insulin merupakan pendorong dilakukannya kajian regulasi ekspresi reseptor ini dikaitkan dengan nutrisi, obesitas, dan diabetes. Kadar PPARy adiposit meningkat secara bermakna pada tikus yang mendapat pakan tinggi lemak dibanding tinggi karbohidrat (6). Sebaliknya, puasa 48 jam menurunkan ekspresi PPARy di jaringan lemak subkutan maupun viseral (3).

Tabel 3. Distribusi PPARy dari hasil analisis dengan Corel Draw versi 11

\begin{tabular}{ll}
\hline Perlakuan & Mean \pm SD \\
\hline Kontrol & $164,29 \pm 14,79^{\mathrm{a}}$ \\
\hline $4 \mu \mathrm{M}$ PUFA & $151,79 \pm 12,58^{\mathrm{b}}$ \\
\hline $8 \mu \mathrm{M}$ PUFA & $161,34 \pm 14,03^{\mathrm{a}}$ \\
\hline $16 \mu \mathrm{M}$ PUFA & $128,27 \pm 13,47^{\mathrm{b}}$ \\
\hline
\end{tabular}

Keterangan.

Notasi yang sama menunjukkan tidak berbeda nyata sedangkan notasi yang berbeda menunjukkan berbeda signifikan $(p \leq 0.05)$.

Penelitian ekspressi PPARy pada lemak subkutan pada 14 subyek berat badan ideal dan obese menunjukkan peningkatan ekspresi mRNA PPARy2 pada individu obese, demikian juga pada rasio PPARy2 / y1 terhadap massa lemak tubuh (BMI) $(4,5)$. Diet rendah kalori pada individu obese juga menyebabkan penurunan (down-regulation) ekspresi mRNA PPARy2 di jaringan lemaknya.

Beberapa penelitian melaporkan bahwa asam linoleat menurunkan massa jaringan lemak, memicu resistensi insulin dan lipodistrofi $(5,7,9)$, namun demikian, mekanisme yang mendasari efek tersebut masih belum jelas. Hasil penelitian menunjukkan bahwa asam linoleat terkonjugasi (Cojugated Lnoleic Acid, (CLA)) menurunkan kadar trigliserida dalam kultur sel stroma vaskuler yang mengandung adiposit manusia yang terdeferensiasi melalui jalur sinyal transduksi MAPK / ERK-dependent transcriptional yang mengendalikan ekspresi gen yang mengatur ambilan glukosa dan asam lemak serta metabolisme sel (10).

Pengendalian kadar leptin oleh diet sudah dibuktikan oleh beberapa peneliti. Peningkatan kadar leptin pada diet tinggi lemak sudah diketahui dari beberapa model penelitian, antara lain pada tikus Sprague-Dawley (11). Akan tetapi efek dari tipe lemak dalam diet terhadap ekspresi leptin masih belum diketahui. Penelitian untuk mengungkap pengendalian jangka panjang leptin plasma oleh diet asam lemak tak jenuh (PUFA) pada tikus resisten insulin akibat pemberian pakan sukrosa jangka panjang telah dilakukan oleh beberapa peneliti. Penurunan kembali kadar leptin setelah pemberian minyak ikan selama 6 minggu setelah sempat meningkat pada pemberian 3 minggu pada tikus resisten insulin akibat diet sukrosa menunjukkan adanya inkonsistensi efek PUFA dalam minyak ikan setelah pemberian jangka panjang (12)

Peningkatan kadar PPARy di adiposit setelah pemberian PUFA dari minyak jagung menunjukkan terjadinya peningkatan ekspresi PPARy yang diinduksi oleh kandungan PUFA pada minyak jagung. Temuan ini sesuai dengan peran PUFA sebagai ligand PPARy. Di samping itu, pemberian PUFA pada penelitian ini juga menyebabkan peningkatan kadar Leptin di medium kultur. Hal ini menunjukkan adanya induksi PUFA terhadap ekspresi leptin di adiposit. Selanjutnya asosiasi yang kuat dan konsisten antara kadar PPARy dan leptin pada penelitian ini menunjukkan bahwa peningkatan ekspresi leptin di adiposit terjadi melalui rantai sinyal transduksi melibatkan PPARY.

Peningkatan PPARy dan leptin dibawah pengaruh PUFA minyak jagung pada penelitian ini ternyata tidak konsisten, dimana terjadi penurunan pada pemberian PUFA 8 $\mu \mathrm{M}$ yang kemudian meningkat lagi pada pemberian $16 \mu \mathrm{M}$. Inkonsistensi tersebut memiliki kemiripan dengan hasil penelitian yang melaporkan penurunan respons ekspresi leptin setelah pemberian minyak ikan selama 6 minggu. Walaupun penelitian ini menggunakan minyak jagung sebagai sumber PUFA, tetapi kemiripan tersebut kemungkinan terjadi oleh sebab ketidak samaan alur sinyal transduksi antara jenis PUFA yang terkandung dalam minyak jagung maupun minyak ikan dalam mempengaruhi ekspresi PPARy maupun leptin adiposit $(11,13)$.

Adanya peran PPARy dalam menstimulasi ekspresi leptin yang ditunjukkan pada penelitian ini lebih mengkonfirmasikan hasil penelitian terdahulu. Dengan demikian dapat disimpulkan bahwa PUFA dalam minyak jagung dapat meningkatkan kadar leptin melalui peningkatan PPARY. Temuan ini dapat digunakan untuk mendasari peran PUFA sebagai nutrien asam lemak dalam menghambat atau mengurangi obesitas. Hal ini didasarkan atas peran leptin sebagai umpan balik negatif ke sistem syaraf pusat melalui 
penghambatan pusat lapar, meningkatkan laju metabolisme sel, dan meningkatkan penggunaan energi.

\section{KESIMPULAN}

Polyunsaturated fatty acid (PUFA) dalam minyak jagung dapat meningkatkan kadar leptin melalui aktifasi PPARY.

\section{DAFTAR KEPUSTAKAAN}

1. Steven DC. Polyunsaturated Fatty Acid Regulation of Gene Transcription: A Molecular Mechanism to Improve the Metabolic Syndrome. American Society for Nutritional Sciences 2001.

2. Yasuki K, Satoshi M, Keiji E, Hiroshi S, and Tohru K. Regulation of Insulin-like Growth Factor-I Expression in Mouse Preadipocyte Ob1771 Cells. 1996; 271(17): 9883-9886

3. Maffei M, Halaas J and Ravussin E. Leptin Levels in Humans and Rodent: Measurement of Plasma Leptin and ob RNA in Obese and Weight Reduced Subjects. Nat. Med 1995; 1:1155-1161

4. MacDouglas OA, Hwang CS and Fan H. Regulated Expression of The Obese Gene Product (Leptin) in White Adipose Tissue and 3T3-L1 Adipocytes. USA: Proc. Natl. Acad. Sci; 1995; 92: 9034-9037.

5. Caro J, Sinha M and Kolaczynski J. Leptin The Tale of an Obesity Gene. Diabetes 1996; 45:1455-1462

6. Kolaczynski H, Ogawa Y and Hosoda K. Augmented Expression of The Obese Gene in The Adipose Tissue From Rat Fed High-Fat Diet. Biophys. Res. Commun. Biochem 2001; 216: 355-358

7. Fried S K and Moussa N M. Culture of adipose Tissue and Isolated Adipocytes.Methods in Molecular Biology Adipose Tissue Protocols. Alhaud G (Ed.)Totowa, New Jersey: Human Press; 2001; 197-212.

8. Lombardo YB, Drago S, Chicco A, Fainstein-Day P, Gagliardino JJ and Gomez-Dumm CL. Long Term Administration of Sucrose-Rich Diet to Normal Rats: Relationship between Metabolic and Hormonal Profiles and Morphological Changes in The Endocrine Pancreas. Metabolism 2002; 45: 1527-1532

9. Clarke SD. Polyunsaturated Fatty Acid Regulation of Gene Transcription: a Mechanism to Improve Energy Balance and Insulin Resistance. Br. J. Nutr 2000; 83: S59-S66

10. Brown V. Clinical Interest of Ppars Ligands. Particular Benefit in Type 2 Diabetes and Metabolic Syndrome Diabetes Metab. 2004; 30; 7-12

11. Bidlingmaler M and Mathias T. Immunoassays Measurement of Leptin in Molecular Biology Adipose Tissue Protocols. Alhaud G (Ed.)Totowa, New Jersey: Human Press; 2001; 323-330.

12. Peyron-Caso E, Fluteau-Nadler S, Kabir M, Guerre-Millo, Quignard-Boulange A, Slama G and Rizkalla SW. Regulation of Glucose Transport and Transporter-4 (GLUT-4) in Muscle and Adipocyte of Sucrose-Fed Rats: Effects of N3 Poly And Monounsaturated Fatty Acids. Horm. Metab. Res. (in press) 2002.

13. Zuo X, Wu Y, Morris JS, Stimmel JB, Leesnitzer LM, Fischer SM, Lippman SM, and Shureiqi I. Oxidative Metabolism of Linoleic Acid Modulates PPAR-Beta / Delta Suppression of PPAR-Gamma Activity. Oncogene advance online publication, 14 November 2005. 
14 Jurnal Kedokteran Brawijaya, Vol. XXI, No. 2, Agustus 2005 